\title{
SCENE SETTING ACTIVITIES: ONE OF STUDENTS' LEARNING MOTIVATION FACTOR
}

\author{
Ansar, Ahmad Afiif, and Eka Damayanti* \\ Department of Biology Education, Faculty of Teacher Training and Education, \\ Universitas Islam Negeri Alauddin Makassar, South Sulawesi, Indonesia \\ *Corresponding e-mail: eka.damayanti@uin-alauddin.ac.id
}

\begin{abstract}
Apperception in the beginning of teaching and learning proccess is common activity done by teacher, which determine the effectiveness of the process. This study aimed to determine the relation between scene setting in the beginning of learning process and student's learning motivation. The population was seventh grade students at MTs. Madani Alauddin Pao Pao in this correlational research. The number of samples were sixty students, taken from $50 \%$ of the population by using simple random sampling. The instruments used were scene setting activity observation sheet and motivational questionnaire sheet, the both used Likert scale. The data obtained were analyzed using simple linear regression analysis. The results indicated that there was a significant correlation between the scene setting and students' learning motivation in Integrated Science subject in class VII of MTs. Madani Alauddin Pao Pao ( $p<0.05)$. The relation between scene setting and learning motivation was in a strong category $(R=0.600)$. Thus, the better the scene setting activities, the more optimum the students' motivation.
\end{abstract}

Keywords: Apperception, learning motivation, scene setting

(C) 2018 Department of Biology Education, FTTE, University of Muhammadiyah Malang, Indonesia

\section{INTRODUCTION}

Education is an important factor in creating human resources (Bangay, 2016). Improvement of learning activities in an essential step due to the quality of education will affect the quality of nation. Through good and high quality education, the community is expected to be able to become noble, dignified, and knowledgeable person, as well as responsible for themselves, the family, community, and nation.

Teacher is one of the main components in education, especially in formal education. During designing the learning, teacher should be familiar with various learning models and strategies so that the learning subject can be easily understood by students (Khalil \& Elkhider, 2016). The importance of these models is certainly an urgent matter for education personnel (Apriyanto, 2013). Through the right learning model, the learning objectives will be achieved optimally.

Besides learning model, various intrinsic factors may influence the level of students' learning outcomes. One of the most important intrinsic factors is student's learning motivation. Learning motivation plays an important role in the learning process because through learning motivation, students are encouraged to make behavioral changes in cognitive, affective and psychomotor aspects. Learning motivation is also able to encourage students to learn actively, creatively, effectively, innovatively and pleasantly (Suhana, 2016).

Learning motivation is a very important aspect to guarantee teaching success. Without motivation, it is impossible for students to have the willingness to learn. With high motivation, students will not be easily despair when they fail in the learning process, despite facing various difficulties (Probowening, Sopyan, \& Handayani, 2014). Therefore, arousing motivation to learn is one of the roles and tasks of educators in each learning process.

Several factors were informed influencing the learning motivation. Those several factors are: (1) aspirations, (2) the ability of students, (3) the condition of students, (4) environmental conditions of students, (5) dynamic elements in learning, and (6) the efforts of teachers in teaching students (Dimyati, 2013). In addition, 
Muliani, Sumardi, and Munir (2015) describes various aspects which may influence learning motivation, namely: (1) health, (2) attention, (3) interest (4) talent (5) ideals, (6) learning abilities, (7) physical condition and spirituality, (8) the condition of the classroom environment, (9) the dynamic elements of learning and (10) the teacher's performance.

Furthermore, the low of students' motivation is one of the causes of many learning activities failed to achieve their learning goals. If students are not motivated to learn, students will not fully prepare to receive lessons. As a result, students will not be able to receive information optimally during learning. This condition will cause students to fail in achieving academic success.

However, learning cannot be separated from activity designed by the teacher. Regarding student motivation, teachers are also expected to be able to design learning activities that can increase the learning motivation of their students. Therefore, teachers must think critically and creatively in designing the learning they will organize. The teacher can choose tricks, tactics, techniques, methods, models, media, until certain learning activities were reported to be able to increase student motivation (Ambrosi-randi \& Ruži, 2010; Chiang \& Lee, 2016; Espinar Redondo \& Ortega Martín, 2015; Lin, Chen, \& Nien, 2014; Movahedzadeh, Patwell, Rieker, \& Gonzalez, 2012; Widiansyah, Indriwati, Munzil, \& Fauzi, 2018).

One activity that may increase student motivation is scene setting. Scene setting is a learning activity carried out by the teacher before starting the main activity. The aim of this activity is to build the initial concept as well as improving the learning motivation of students (Chatib, 2016). This activity helps students to instill their intrinsic encouragement or motivation to complete learning goals (Candra, 2015).

Several resources suggest that scene setting activity is one of apperception activities in learning. Apperception is a collection of students' past learning experiences that are associated with new experiences in learning that students will take (Suhana, 2016). With scene setting, the teacher will not start the learning material directly. Teachers or students begin learning by discussing initial experiences or explaining the benefits of learning topics in the real life. Apperception can be presented through questions to find out whether students still remember or forget the previous learning experience they have received and whatever they have understood about the topic to be studied (Rohani, 2010).

There are various scene setting activities that can be applied by the teacher, e.g.: (1) storytelling, (2) visualization, (3) simulation, (4) pantomime, and (5) bringing in figures (Chatib, 2016). To start apperception or scene setting, four ways can be conducted. First, the teacher can do ice breaking which aims to generate enthusiasm and consolidate learning concepts. Second, the teacher can tell fun stories, especially related to the subject matter to be delivered with the aim of attracting more attention and students' interest in learning. Third, the teacher can play music that aims to restore brain waves back to the alpha zone or create pleasant, motivating and inspiring conditions. Fourth, the teacher can do brain exercises with a series of exercises with simple body movements to stimulate the performance of the left and right hemispheres.

Scene settings play an important role in optimizing the learning process. However, until now, research that examines how the relationship of scene setting to various parameters in the learning process is still difficult to find. Furthermore, research that examines student learning motivation often only relates it to the implementation of certain learning forms (Harandi, 2015), learning model (Argaw, Haile, Ayalew, \& Kuma, 2017; Chiang \& Lee, 2016), or learning media (Widiansyah et al., 2018).

Based on the result of the preliminary observation at MTs. (Madrasah Tsanawiyah or Islamic Junior High School) Madani Alauddin Pao Pao, teachers often conduct scene settings at the beginning of learning. Storytelling and simulation were the most frequently observed scene settings activities in the class. Therefore, research that examines the activity of scene settings in this school needs to be conducted. In this study, the correlation between scene setting activities and student motivation in this school was assessed.

\section{METHOD}

This study was a correlational research aimed to find the relation between scene setting and students' learning motivation on the Integrated Science subject. The population in 
Ansar et al. / JPBI (Jurnal Pendidikan Biologi Indonesia) / 4 (3) (2018) pp. 251-256

this study was all students in class VII of MTs. Madani Alauddin Pao Pao. The sample in this study was $50 \%$ (sixty students) from the population of class VII at this school. Research samples taken by using simple random sampling.

The instrument used were motivational questionnaire sheet and scene setting activity observation sheet. Both of instruments used a Likert scale. The scale of learning motivation was measured based on aspects of (a) persistence in learning, (b) independence in learning (c) willingness and desire to succeed, and (d) the interest and sharpness of attention in learning. While the scene setting was measured through the learning activities conducted by the teacher in the learning process before delivering the core material.

The data obtained were then analyzed using simple linear regression analysis. SPSS was chosen as program for analyzed the data. The significance level used in this analysis was $5 \%$.

\section{RESULTS AND DISCUSSION}

Motivation is an important factor in determining student learning success. In this study, the interconnected between motivation and scene setting activity was assessed. After the data met the normality and linearity assumption, the data were analyzed using regression analysis. The results can be seen in the Table 1.

Table 1. The results of regression analysis

\begin{tabular}{llll}
\hline $\mathbf{R}$ & R Square & F & Sig \\
\hline .600 & .360 & 32.638 & $<.05$ \\
\hline
\end{tabular}

Based on Table 1, F value was 32.638 with $p$ $<0.05$. This result indicated that the regression model obtained from this study was statistically significantly predict the students' learning motivation. Furthermore, the R-value obtained from data analysis was 0.600. This value illustrated that the correlation/relationship between scene setting and learning motivation was in the strong category. Whereas, the $\mathrm{R}^{2}$ value was 0.360 , which implied that students' learning motivation could be explained as much as $36 \%$ by scene setting activity conducted by teacher. On the other hand, the other $64 \%$ result were influenced by other variables that was not observed in this study. Then, the coefficents of linear regression line obtained can be seen in Table 2.
Table 2. Linear regression line equation

\begin{tabular}{llllll}
\hline \multirow{2}{*}{ Model } & \multicolumn{2}{c}{$\begin{array}{c}\text { Unstandardized } \\
\text { Coefficients }\end{array}$} & \multirow{2}{*}{ t } & Sig. \\
\cline { 3 - 4 } & & B & Std. Error & & \\
\hline 1 & (Constant) & 20.215 & 14.517 & 1.392 & .169 \\
& X & .909 & .159 & 5.713 & $<.05$ \\
\hline
\end{tabular}

Based on Table 2, the linear regression equation can be written as $\mathrm{Y}=20.215+$ $0.909 \mathrm{X}$. This means that without the scene setting, student's learning motivation was 20.215. The equation shows the "+" sign that describes a positive relationship. This means that the scene setting increases learning motivation. Therefore, each addition of one scene setting unit will be followed by an increase of 0.909 in the value of student's learning motivation.

The results obtained from the present study is in line with the results from Palupi, Anitah, and Budiyono (2014). Palupi has reported that there is a relationship between student learning motivation and teacher performance in learning activities. Safitri, Maulana, and Damayanti (2018) also found that the activities designed by teachers in learning was very important on learning achievement, for example by applying Quick on The Draw learning strategies. The implementation of the strategy can increase learning motivation.

In addition, the information from the study is also in line with Candra (2015) who pinpoints that scene setting is significant for students in order to have an urge from themselves or intrinsic motivation to learn. Comparing with the research by the Sekolastika Elyana, Khosmas, and Okianna (2015), the study found that teacher teaching variations through teacher interaction with students and eye contacts have contributed $10.9 \%$ in increasing student's motivation. This study, however, records a higher percentage of student's learning motivation. However, on the other study, Apriyanto (2013) have reported that the scene setting have not a significant effect on students' motivation. However, the average of achievement on class that got scene setting is higher than the other class.

The results from this present study are consistent with the interview results. From the interview, it was suggested that the Integrated Science teacher often did scene setting activities, including telling their experiences while relating to the science materials. The teacher also conducted simulations when energy subject matter was delivered. Before the 
learning starts, the teacher asked the students to bring lunchbox from their homes. After they ate, the teacher asked "What do you feel after eating?" Then the student answered "We are full, Ma'am". After that the teacher explained that what they had done was related to the subject matter to be studied. Students were encouraged to think more.

The use of scene setting activity before the core material will certainly make students build the initial concept of learning and increase learning motivation. Scene setting can be conducted by various methods, such as; storytelling, pantomime, simulation, and inviting ideal figures directly to class. In MTs. Madani Alauddin Pao Poan, the scene settings storytelling and simulation were the most often activites during scene setting.

In addition, according to the statement from Dra. Besse Aisyah, one of the science teachers in grade VII MTs, the implementation of the scene setting was very good. This activity instills children's motivation to learn science, because the science learning is often associated with everyday life and everyday usage.

From the results, it can be concluded that the use of scene setting is deemed important to be carried out before the learning process takes place. This is in line with the functions of the scene setting presented by Chatib (2016). Chatib explained scene setting could build the concept of learning, providing learning experiences before starting the core material, reducing instruction, and arousing students' curiosity.

Furthermore, the functions of the scene setting are (1) to build the concept at the beginning of learning, (2) to provide a learning experience before learning the core material, (3) to reduce instruction, and (4) to raise students' curiosity (Chatib, 2016). Whereas according to Suhana (2016), there are several functions of apperception or scene setting; (1) New experiences are easily accepted when associated with the previous experiences to achieve effective learning. (2) Previously received experience may color the new experience as an integral part of modifying new behavior. (3) Apperception can develop interest and attention in learning, so that openness to receive new experiences in learning is more prepared and enjoyable.

The function of the scene setting is to motivate students to learn. Learning motivation according to Sardiman (2016) is an effort that encourages someone to learn. Motivation play an important role in learning process. Students who have strong motivation will possess a lot of energy to do learning activities. Therefore, motivation usually can overcome the problem related to the presence of difficult concepts in some subject matter.

Biology is one branch of science that studies several difficult concepts (Çimer, 2012; Fauzi \& Fariantika, 2018; Fauzi \& Mitalistiani, 2018; Ozcan, Ozgur, Kat, \& Elgun, 2014). The existence of these difficult concepts will hinder the maximum achievement of student learning outcomes. However, by utilizing the information obtained from this study, educators have the opportunity to optimize the achievement of student learning outcomes. This information is scene setting is an essential component of biology learning. Higher motivation to learning, higher the academic achievement of the student. Thus, by designing good scene setting, student could achieve learning outcome optimally due to they are motivated to learn.

\section{CONCLUSION}

The implementation of scene setting in the learning process is proven has correlation on student's learning motivation. Scene setting activity has also could predict the learning motivation of the students $(p<0.05)$. Each addition of one scene setting unit would be followed by an increase of 0.909 in the value of students' learning motivation in Integrated Science subject, class VII, MTs. Madani Alauddin Pao Pao. Thus, the practice of scene setting is potential to be developed in further learning process.

From the information obtained, scene setting is an essential activity during apperception. The implementation of this activity have a good impact on the motivation of students to learn. Therefore, it is recommended to the teacher to could design the scene setting activities before they start the learning.

\section{REFERENCES}

Ambrosi-randi, P. N., \& Ruži, H. (2010). Motivation and learning strategies in university courses in Italian Language. Metodički Obzori, 10(5), 41-50. Retrieved from https://hrcak.srce.hr/file/98889

Apriyanto, A. (2013). Studi komparasi 
Ansar et al. / JPBI (Jurnal Pendidikan Biologi Indonesia) / 4 (3) (2018) pp. 251-256

penggunaan alfa zone dengan scene setting terhadap motivasi belajar muatan IPA siswa kelas IV SDIT MTA Gemolong Sragen. Universitas Muhammadiyah Surakarta.

Argaw, A. S., Haile, B. B., Ayalew, B. T., \& Kuma, S. G. (2017). The effect of problem based learning (PBL) instruction on students' motivation and problem solving skills of physics. Eurasia Journal of Mathematics, Science and Technology Education, 13(3), 857-871. https://doi. org/10.12973/eurasia.2017.00647a

Bangay, C. (2016). Protecting the future: The role of school education in sustainable development - an Indian case study. International Journal of Development Education \& Global Learning, 8(1), 5-19. Retrieved from http://10.0.72.114/IJD EGL.8.1.02\%0Ahttps://unco.idm.oclc.org/ login?url=http://search.ebscohost.com/logi n. asp $x$ ?direct $=$ true $\& \mathrm{db}=$ eue $\& \mathrm{AN}=121334$ $442 \&$ site $=$ ehost-live

Candra, M. D. (2015). Penerapan pembelajaran berbasis multiple intelligences pada siswa di SD Juara Gondokusuman Yogyakarta. Basic Education, 4(12), 1-13. Retrieved from http://journal.student.uny.ac.id/ojs/in dex.php/pgsd/article/download/1140/1012

Chatib, M. (2016). Gurunya manusia. Bandung: Kaifa.

Chiang, C. L., \& Lee, H. (2016). The Effect of project-based learning on learning motivation and problem-solving ability of vocational high school students. International Journal of Information and Education Technology, 6(9), 709-712. htt ps://doi.org/10.7763/IJIET.2016.V6.779

Çimer, A. (2012). What makes biology learning difficult and effective: Students' views. Educational Research and Reviews, 7(3), 61-71. https://doi.org/10.5897/ERR11.205

Dimyati, M. (2013). Belajar dan pembelajaran. Jakarta: PT Rineka Cipta.

Elyana, S., Khosmas, F. Y., \& Okianna. (2015). Pengaruh variasi mengajar terhadap motivasi belajar siswa kelas XI pada mata pelajaran ekonomi SMA PGR 1 Pontianak. Jurnal Pendidikan Dan Pembelajaran, 4(7).

Espinar Redondo, R., \& Ortega Martín, J. L. (2015). Motivation: The road to successful learning. PROFILE Issues in Teachers' Professional Development, 17(2), 125136. https://doi.org/10.15446/profile.v17n
2.50563

Fauzi, A., \& Fariantika, A. (2018). Courses perceived difficult by undergraduate students majoring in biology. Biosfer: Jurnal Pendidikan Biologi, 11(2), 78-89. https://doi.org/10.21009/biosferjpb.v11n2. 78-89

Fauzi, A., \& Mitalistiani. (2018). High school biology topics that perceived difficult by undergraduate students. Didaktika Biologi: Jurnal Penelitian Pendidikan Biologi, 2(2), 73-84. Retrieved from http://jurnal.um-palembang.ac.id/dikbio/ar ticle/download/1242/1067

Harandi, S. R. (2015). Effects of e-learning on students' motivation. Procedia - Social and Behavioral Sciences, 181, 423-430. https://doi.org/10.1016/j.sbspro.2015.04.9 05

Khalil, M. K., \& Elkhider, I. A. (2016). Applying learning theories and instructional design models for effective instruction. Advances in Physiology Education, 40(2), 147-156. https://doi.org /10.1152/advan.00138.2015

Lin, H.-M., Chen, W.-J., \& Nien, S.-F. (2014). The study of achievement and motivation by e-learning-A case study. International Journal of Information and Education Technology, 4(5), 421-425. https://doi. org/10.7763/IJIET.2014.V4.442

Movahedzadeh, F., Patwell, R., Rieker, J. E., \& Gonzalez, T. (2012). Project-based learning to promote effective learning in biotechnology courses. Education Research International, 2012, 1-8. https:// doi.org/10.1155/2012/536024

Muliani, Sumardi, \& Munir, A. R. (2015). Motivasi, komitmen, dan budaya lingkungan belajar terhadap prestas belajar peserta kursus TOEFL preparation pada pusat bahasa Universitas Hasanuddin. Jurnal Analisis, 4(2), 190195.

Ozcan, T., Ozgur, S., Kat, A., \& Elgun, S. (2014). Identifiying and comparing the degree of difficulties biology subjects by adjusting it is reasons in elemantary and secondary education. In Procedia - Social and Behavioral Sciences (Vol. 116, pp. 113-122). Elsevier B.V. https://doi.org/ 10.1016/j.sbspro.2014.01.177

Palupi, R., Anitah, S., \& Budiyono. (2014). Hubungan antara motivasi dan persepsi kinerja guru dalam mengelola kegiatan 
terhadap kinerja guru dalam kegiatan belajar dengan hasil belajar IPA siswa kelas VIII di SMPN N 1 Pacitan. Jurnal Teknologi Pendidikan Dan Pembelajaran, 2(2), 157-170. Retrieved from http:// jurnal.fkip.uns.ac.id/index.php/tp/article/d ownload/3661/2562

Probowening, P. R., Sopyan, A., \& Handayani, L. (2014). Pengembangan strategi pembelajaran fisika berdasarkan teori kecerdasan majemuk untuk meningkatkan motivasi dan hasil belajar siswa SMP. Unnes Physics Education Journal, 3(1). https://doi.org/10.15294/upej.v3i1.3117

Rohani, A. (2010). Pengelolaan Pengajaran. Jakarta: Rineka cipta.

Safitri, N. A., Maulana, A., \& Damayanti, E. (2018). Pengaruh penerapan strategi pembelajaran quick on the draw terhadap motivasi dan hasil belajar siswa SMP Negeri 3 Pallangga. Jurnal Biotek, 6(1), 43-52.

Sardiman, S. (2016). Interaksi dan motivasi belajar mengajar. Jakarta: Rajawali Press.

Suhana, C. (2016). Konsep strategi pembelajaran. Bandung: Refika Aditama.

Widiansyah, A. T., Indriwati, S. E., Munzil, \& Fauzi, A. (2018). I-invertebrata as an android-based learning media for molluscs, arthropods, and echinoderms identification and its influence on students' motivation. JPBI (Jurnal Pendidikan Biologi Indonesia), 4(1), 4352.https://doi.org/10.22219/jpbi.v4i1.5476 